\title{
Presence of Toxocara spp. and Other Zoonotic parasites Ova in Children's Playground in Karaman, Turkey
}

\author{
Türkiye'nin Karaman İlinde Çocuk Oyun Parklarında Toxocara spp. ve \\ Diğer Zoonoz Parazitlerin Yumurtalarının Varliğı
}

\author{
(1) Mehmet Fatih Aydın \\ University of Karamanoğlu Mehmetbey Faculty of Health Sciences, Department of Public Health, Karaman, \\ Türkiye
}

Cite this article as: Aydın MF. Presence of Toxocara spp. and Other Zoonotic Parasites Ova in Children's Playground in Karaman, Turkey. Turkiye Parazitol Derg 2020;44(1):17-20

\begin{abstract}
Objective: Human toxocariosis (HT) is a widespread and neglected parasitic disease around the world and it is caused by Toxocara canis and Toxocara cati, a common nematode found in dogs and cats. Childiren are caught to HT after ingestion of embriyonated Toxocara spp. eggs via contaminated materials such as soil, hair and etc. The aim of this study is to investigate Toxocara spp. and other zoonotic parasites in children's playgrounds in Karaman province of Turkey.

Methods: In total, 103 samples (68 sand soil, 26 soil and 9 stool) from 20 randomly selected children's playgrounds in May 2018 in Karaman province, were investigated. Samples were examined by flotation in saturated $\mathrm{NaCl}$ solution and parasite ova were diagnosed under the light microscope morphologically.

Results: Of the 20 screened playgorunds, 11 [55\%, confidence interval (CI=33.6-75.2)] and 27 analyzed sample (26.2\%, CI=18.435.2) were positive one or more parasite species. While Toxocara spp. eggs were the most common species in total (19.4\%, $\mathrm{CI}=12.6-27.8)$, taeniid (Taenia spp., Echinococcus spp.) eggs and Ancylostoma spp. eggs were found in seven (6.8\%, CI=2.97-12.7) and one $(0.97 \%, C I=0.05-4.21)$ samples respectively. Also, one soil sample was found to be contaminated with both Toxocara and taeniid eggs.

Conclusion: These results demonstrate that children's playgrounds in Karaman may be a source for HT and other zoonotic infections. We advise to be fenced children's playgrounds in order to prevent pet animal's accessibility.

Keywords: Toxocara, soil, playground, Karaman, Turkey

\section{ÖZ}

Amaç: İnsan toksokariosisi (İT) köpek ve kedilerde yaygın olarak bulunan nematod Toxocara canis ve Toxocara cati'den kaynaklanan, dünya çapında yaygın ve ihmal edilen paraziter bir hastalıktır. Çocuklar İT'ye toprak, saç vb. gibi kirli malzemelerle embriyonlu Toxocara spp. yumurtalarını alarak yakalanırlar. Bu çalışmanın amacı Türkiye'nin Karaman ilindeki çocuk oyun alanlarındaki Toxocara spp. ve diğer zoonotik parazitleri araştırmaktır.

Yöntemler: Rastgele seçilen 20 çocuk oyun alanından toplamda 103 (68 kumlu toprak, 26 toprak ve 9 dışkı) örnek 2018 yılı mayıs ayında alınmıştır. Örnekler doymuş $\mathrm{NaCl}$ çözeltisi içinde yüzdürme metodu ile incelenmiş ve parazit yumurtaları 1şık mikroskobu altında morfolojik olarak teşhis edilmiştir.

Bulgular: Taranan 20 oyun alanından 11'i (\%55, CI=3,6-75,2) ve 27 numune (\%26,2, CI=18,4-35,2) bir veya daha fazla parazit türü olarak pozitifti. Toxocara spp. yumurtaları belirlenen en yaygın türler iken (\%19,4, CI=12.6-27.8), taeniid (Taenia spp., Echinococcus spp.) ve Ancylostoma spp. yumurtalar1 sirasiyla yedi (\%6.8, CI 2.97-12.7) ve bir (\%0.97, CI=0.05-4.21) numunede bulundu. Ayrıca, bir toprak örneğinin hem Toxocara hem de taeniid yumurtaları ile kirlenmiş olduğu bulundu.

Sonuç: Bu sonuçlar, Karaman'daki çocuk oyun alanlarının İT ve diğer zoonotik enfeksiyonlar için bir kaynak olabileceğini göstermektedir. Evcil hayvanların erişimini engellemek için çocuk oyun alanlarının çitle çevrilmesini tavsiye ediyoruz.

Anahtar Kelimeler: Toxocara, toprak, oyun alanı, Karaman, Türkiye
\end{abstract}

Bu çalışma 21. Parazitoloji Kongresi'nde (28 Eylül - 3 Ekim 2019, İzmir) poster bildirisi olarak sunulmuştur.

Geliş Tarihi/Received: 26.12.2018 Kabul Tarihi/Accepted: 03.01.2020

Yazar Adresi/Address for Correspondence: Mehmet Fatih Aydın DVM, University of Karamanoglu Mehmetbey Faculty of Health Sciences, Department of Public Health, Karaman, Türkiye

E-Posta/E-mail: veterinermfa@gmail.com ORCID ID: orcid.org/0000-0002-8325-4887

(C) Copyright 2020 Turkish Society for Parasitology - Available online at www.turkiyeparazitolderg.org

C) Telif hakkı 2020 Türkiye Parazitoloji Derneği - Makale metnine www.turkiyeparazitolderg.org web sayfasından ulașılabilir. 


\section{INTRODUCTION}

Children are exposed to a wide range of zoonotic parasitic diseases while playing in public parks or playgrounds $(1,2)$. Toxocara canis ( $T$. canis) and Toxocara cati (T. cati), a common nematode found in dogs and cats $(3,4)$, cause human toxocariosis (HT) or visceral larva migrans in general population (5). The disease is occurring after ingestion of embriyonated Toxocara spp. eggs via contaminated soils with pup feces and unwashed vegetables (6). Consumption of raw or semi-cooked meat containing larvae, contact with dogs, soil eating or pica and drinking unboiled water are among risk factors for HT $(1,5,7)$.

Because of the public importance, more research was conducted to determine presence and frequency of Toxocara spp. and other parasites found in public areas worldwide (8-11). The purpose of this research is to determine Toxocara spp. and other potential parasites likely to be in children's playgrounds in Karaman province of Turkey, where no study was conducted for this aim.

\section{METHODS}

This study was conducted in Karaman province, located at ( $37^{\circ} 10^{\prime}$ 51.632" N 33 $3^{\circ} 13^{\prime} 20.075^{\prime \prime}$ E) coordinates in south of the Central Anatolia Region of Turkey. The province is about 1033 meters above sea level and has a surface area of $8869 \mathrm{~km}^{2}$. While townwide show continental climate features, southern parts can shows temperate climate characteristics. The average annual percentage of relative humidity is $58 \%$ in Karaman.

Overall, 103 samples (68 sand soil, 26 soil and 9 stool) were collected from 20 children's playgrounds during May of 2018. Five samples were taken from each playground at least. For soil sampling, 250 gram specimen was taken from the $7 \mathrm{~cm}$ of ground in to plastic bags and examined within that day or on the following day. Soil samples were examined by flotation in saturated $\mathrm{NaCl}$ solution (12). In a big beaker 250 gr soil samples were homogenized with saturated $\mathrm{NaCl}$ solution $\left(25^{\circ} \mathrm{C}\right.$ is 1.2 $\mathrm{g} / \mathrm{m}$ ). Then it was filtered in to a small glass, in order to remove coarse particles. Saturated $\mathrm{NaCl}$ solution was again added on to homogenized sample and coverglass was placed on to mix. After 20 min incubation cover glass was taken attentively and examined under the light microscope (objective: 40x). Toxocara spp. eggs were diagnosed according to spherical shape, serrated surface and thick dark shell morphological properties.

\section{Statistical Analysis}

For statistical analysis Statistical Package for the Social Science (SPSS) version 16.0 (SPSS Inc., Chicago, IL, USA) package programme was used. Pearson's chi-square test was used to evaluate qualitative data. Statistical significance was evaluated at levels of 0.05 and 0.01. Maximum likelihood estimation with $95 \%$ confidence intervals $(\mathrm{CI})$ of contamination rates was also calculated.

\section{RESULTS}

As seen in Table 1, 11 of 20 playgrounds (55\%, CI=33.6-75.2) and 27 of 103 samples (26.2\%, CI=18.4-35.2) were found to be contaminated one or more parasite species eggs. While Toxocara spp. eggs were the most common species in total (19.4\%, CI=12.627.8), taeniid (Taenia spp., Echinococcus spp.) and Ancylostoma spp. eggs were found in seven $(6.8 \%, C I=2.97-12.7)$ and one $(0.97 \%, C I$ $0.05-4.21$ ) sample respectively. Also, one soil samples was found to be contaminated both Toxocara and taeniid eggs.

\section{DISCUSSION}

Soil transmitted diseases are rapidly increasing worldwide due to the out-of-controlled pet animals, failures in antiparasitic treatment in animals and etc. $(2,13)$. According to a recent metaanalysis, global prevalence of Toxocara spp. eggs in the world was $21 \%$ (14). This rate was reported as $16 \%$ for Turkey in the same study. Also high longitude and humidity was associated with high prevalence of Toxocara in environment (14). Toxocara egg. prevalence in children's playground was $19.4 \%$ in this study. In spite of this rate was higher than the prevalence for Turkey (16.0\%), it is in accordance with the global prevalence reported by Fakhriet et al. (14). This finding be correlated with humidity rates and large population of stray dogs in the province. Toxocara spp. eggs in different provinces of Turkey vary from $4.16 \%$ to $64.28 \%$. Toxocara eggs prevalence in soil samples was $4.16 \%$ in Konya (15), 7.3\% in Kayseri (16), 8.33\% in Istanbul (8), 10\% in Kütahya (17), 15.05\% in Ankara (18), 15.6\% in Kirıkkale (19),

\section{Table 1. Distribution of Toxocara, Taenia and Ancylostoma eggs in the samples}

\begin{tabular}{|l|l|l|l|l|l|l|l|l|}
\hline Sample & $\begin{array}{l}\text { NCS/ } \\
\text { NAS }\end{array}$ & NPS & $\begin{array}{l}\text { MLE } \\
\mathbf{( \% )}\end{array}$ & $\mathbf{9 5 \%}$ CI & $\begin{array}{l}\text { Toxocara spp. } \\
\text { egg }\end{array}$ & Taenia spp. egg & $\begin{array}{l}\text { Toxocara+ Taenia } \\
\text { spp. egg }\end{array}$ & Anclostoma spp. egg \\
\hline Playground & $20 / 20$ & 11 & 55 & $33.6-75.2$ & $\begin{array}{l}6 / 20(30 \%)^{a} \\
\text { CI } 13.2-51.7\end{array}$ & $\begin{array}{l}6 / 20(30 \%) \\
\text { CI } 13.2-51.7\end{array}$ & $\begin{array}{l}1 / 20(5 \%) \\
\text { CI } 0.29-20.2\end{array}$ & $\begin{array}{l}1 / 20(5 \%) \\
\text { CI } 0.29-20.2\end{array}$ \\
\hline Sandy soil & $68 / 68$ & 17 & 25 & $15.8-36.1$ & $\begin{array}{l}12 / 68(17.7 \%) \\
\text { CI } 9.86-27.8\end{array}$ & $\begin{array}{l}5 / 68(7.35 \%) \\
\text { CI } 2.7-15.2\end{array}$ & $0 / 68$ & $0 / 68$ \\
\hline Soil & $26 / 26$ & 7 & 26.9 & $12.6-45.6$ & $\begin{array}{l}6 / 26(23.1 \%) \\
\text { CI } 9.88-41.3\end{array}$ & $\begin{array}{l}2 / 26(7.69 \%) \\
\text { CI } 1.32-21.9\end{array}$ & $\begin{array}{l}1 / 26(3.85 \%) \\
\text { CI } 0.22-15.9\end{array}$ & $0 / 26$ \\
\hline Stool & $9 / 9$ & 3 & 33.3 & $9.54-65.5$ & $\begin{array}{l}2 / 9(22.2 \%) \\
\text { CI } 4.08-54.2\end{array}$ & $0 / 9$ & $\begin{array}{l}0 / 9 \\
\text { CI } 0.66-40.5\end{array}$ \\
\hline Total & $103 / 103$ & 27 & 26.2 & $18.4-35.2$ & $\begin{array}{l}20 / 103(19.4 \%) \\
\text { CI } 12.6-27.8\end{array}$ & $\begin{array}{l}7 / 103(6.8 \%) \\
\text { CI } 2.97-12.7\end{array}$ & $\begin{array}{l}1 / 103(0.97 \%) \\
\text { CI } 0.05-4.21\end{array}$ & $\begin{array}{l}1 / 103(0.97 \%) \\
\text { CI } 0.05-4.21\end{array}$ \\
\hline
\end{tabular}

NCS: Number of collected sample, NAS: Number of analyzed sample, NPS: Number of positive sample, MLE: Maximum likelihood estimation, CI: Confidence intervals athe rate (...\%) shows the MLE result 
$18.91 \%$ in Aydın (20), 23\% in Elazığ (12), 25.97\% in Van (21), and $64.28 \%$ in Erzurum (9), respectively. In this study Toxocara spp. egg prevalence was $19.4 \%$ (20/103, $C I=12.6-27.8)$. The Toxocara eggs prevalence we found in this study was higher than the study conducted in Konya Province (15), a metropolis neighbor to Karaman. This may be due to its being a metropolis, having more financial opportunities of its municipality and being easy of street animal rehabilitation. Also parasite egg. contamination was found lower than Erzurum. This may originate from differences in prevalence of risk factors between Erzurum and Karaman.

Taeniid (Taenia spp., Echinococcus spp.) eggs were found in 7 of 103 samples (6.8\%) and also it was remarkable that 6 of 20 playgrounds (30\%) were contaminated with this parasite. However, Ancylostoma spp. egg was determined in one stool sample (1/103, 0.97\%). Taeniid and Ancylostoma eggs were determined in soil samples in Kayseri province of Turkey with rates of $0.8 \%$ and $0.4 \%$ respectively (16). While prevalence of taeniid eggs with combination of Toxascaris leonina in soil was $0.38 \%$ in Ankara (18), taeniid ova was detected with the rates of $3.12 \%$ and $1.0 \%$ in soils in Erzurum and Kirıkkale $(9,19)$, respectively. Since Ancylostoma spp. eggs are not as resistant to external conditions as taeniid eggs, their prevalence may be lower.

Since cheapness, easy practice and satisfactory results, flotation technique is one of the most preferred methods for detection of Toxocara spp. eggs in soil specimens $(10,18,22,23)$. In addition, Caldwell (24), modified Baermann (25) and polymerase chain reaction $(11,16)$ methods were used for this purpose. In this study we found high prevalence for Toxocara spp. eggs in playgrounds $(6 / 20,30 \%)$ and samples $(27 / 103,26.2 \%)$ with the flotation method. It was evaluated that this technique is still appropriate for detection of soil contamination.

Human toxocariosisis is a widespread and neglected parasitic disease due to lack of personal hygiene, increase of uncontrolled stray dog population and places have suitable environmental conditions around the world including Turkey $(1,5,6,23,26)$. We found high contamination (19.4\%) with Toxoara spp. eggs in this study. This probably will result in high Toxocara spp. infection in the province and we propose prevalence studies concerning HT and to determine risk factors for the disease.

\section{CONCLUSION}

$55 \%$ of playgrounds in Karaman were found to be contaminated with zoonotic parasite eggs. Toxocara spp., taeniid (Taenia spp., Echinococcus spp.) and Ancylostoma spp. ova prevalence were determined as $19.4 \%, 6.8 \%$ and $0.97 \%$ respectively. It is foreseen that these results may induce high human infection in the province. We also recommend children's playgrounds to be fenced to prevent pet animal's accessibility. It is also important that to improve public awareness with training programs.

Acknowledgements: We would like to thank the Karaman municipality for allowing the study.

\section{* Ethics}

Ethics Committee Approval: Ethics committee approval was not received due to working with soil, sand and stool samples in playgrounds.

Informed Consent: No patients were used in the study. Because of working with soil, sand and fecal samples in the playgrounds, patient consent was not obtained.
Peer-review: Internally peer reviewed.

Financial Disclosure: No financial support was received for this study.

\section{REFERENCES}

1. Gyang PV, Akinwale OP, Lee YL, Chuang TW, Orok AB, Ajibaye O, et al. Seroprevalence, disease awareness, and risk factors for Toxocara canis infection among primary school children in Makoko, an urban slum community in Nigeria. Acta Trop 2015;146:135-40.

2. Gordon CA, Kurscheid J, Jones MK, Gray DJ, McManus DP. SoilTransmitted Helminths in Tropical Australia and Asia. Trop Med Infect Dis. 2017;23;2:E56.

3. Çiçek M, Yılmaz H. Van Yöresinde İnsan ve Köpeklerde Toxocariasis'in Yayllı̧ı. Kafkas Univ Vet Fak Derg 2012;18:531-536.

4. Öge H, Öge S, Özbakış G, Gürcan S. Comparison of Toxocara eggs in hair and faecal samples from owned dogs and cats collected in Ankara, Turkey. Vet Parasitol 2014;206:227-31.

5. Aghamolaie S, Seyyedtabaei SJ, Behniafar H, Foroutan M, Saber V, Hanifehpur $\mathrm{H}$, et al. Seroepidemiology, modifiable risk factors and clinical symptoms of Toxocara spp. infection in northern Iran. Trans R Soc Trop Med Hyg 2019;1;113:116-22

6. Selek MB, Baylan O. İnsan toksokariyazı. Turk Hij Den Biyol Derg 2013;70:113-134.

7. Ma G, Holland CV, Wang T, Hofmann A, Fan CK, Maizels RM, et al. Human toxocariasis. Lancet Infect Dis 2018;18:e14-e24.

8. Toparlak M, Gargılı A, Tüzer E, Keleş V, Esatgil M, Çetinkaya H. Contamination of Children's Playground Sand pits with Toxocara eggs in İstanbul, Turkey. Turk J Vet Anim Sci 2002;26:317-20.

9. Avcıoglu H, Balkaya I. The Relationship of Public Park Accessibility to Dogs to the Presence of Toxocara Species Ova in the Soil. Vector Borne Zoonotic Dis 2011;11:177-80.

10. Kleine A, Springer A, Strube C. Seasonal variation in the prevalence of Toxocara eggs on children's playgrounds in the city of Hanover, Germany. Parasit Vectors 2017;10:248.

11. Choobineh M, Mikaeili F, Sadjjadi SM, Ebrahimi S, Iranmanesh S. Molecular characterization of Toxocara spp. eggs isolated from public parks and playgrounds in Shiraz, Iran. J Helminthol 2019;93:306-12.

12. Şimşek S, Ütük AE, Köroğlu E. Elazığ'daki Bazı Okul Bahçelerinde Toxocara spp. Yumurtalarının Yaygınlığı. FÜ Sağ Bil Vet Derg 2005;19:133-36.

13. Traversa D, Frangipanedi Regalbono A, Di Cesare A, La Torre F, Drake J, Pietrobelli M. Environmental contamination by canine geohelminths. Parasites\&Vectors 2014;7:67.

14. Fakhri Y, Gasser RB, Rostami A, Fan CK, Ghasemi SM, Javanian M, et al. Toxocara eggs in public places worldwide - A systematic review and metaanalysis. Environ Pollut 2018;242:1467-1475.

15. Güçlü F, Aydenizoz M. Çocuk parklarındaki kumların kopek ve kedi helminti yumurtaları ile kontaminasyonunun tesbiti. Turkiye Parazitol Derg 1998; 23, 24-7. / 1998;22:194-8.

16. Bozkurt O, Ylldırım A, İnci A, Çiloğlu A, Bişkin Z, Düzlü O. Kayseri İli Parklarında Bulunan Oyun Alanlarının Askarit Türleri İle Kontaminasyonunun Parazitolojik ve Moleküler Yöntemlerle Araştırılması. Kafkas Univ Vet Fak Derg 2012;18:A175-180.

17. Akdemir C. Visceral larva migrans among children in Kütahya (Turkey) and an evaluation of playgrounds for T. canis eggs. Turk J Pediatr 2010;52:158-62.

18. Avcıoglu H, Burgu A. Seasonal Prevalence of Toxocara Ova in Soil Samples from Public Parks in Ankara Turkey. Vector Borne Zoonotic Dis 2008;8:345-50. 
19. Aydenizöz-Ozkayhan M. Soil contamination with ascarid eggs in playgrounds in Kirikkale, Turkey. J Helminthol 2006;80:15-8.

20. Gürel FS, Ertuğ S, Okyay P. Aydın İl Merkezindeki Parklarda Toxocara Spp Yumurta Görülme Sıklığının Araştırılması. Turkiye Parazitol Derg 2005;29:177-9.

21. Ayaz E, Yaman M, Gül A. Prevalence of Toxocara spp. eggs in soil of public parks in Van, Turkey. Indian Vet J 2003;80:574-6.

22. Pezeshki A, Haniloo A, Alejafar A, Mohammadi-Ghalehbin B. Detection of Toxocara spp. Eggs in the Soil of Public Places in and Around of Ardabil City, Northwestern Iran. Iran J Parasitol 2017;12:136-42.

23. Papavasilopoulos V, Pitiriga V, Birbas K, Elefsiniotis J, Bonatsos G, Tsakris A. Soil contamination by Toxocara canis and human seroprevalence in the Attica region, Greece. Germs 2018;8:155-61.
24. Ribeiro LM, Dracz RM, Mozzer LR, Lima WDS. Soil contamination in public squares in Belo Horizonte, Minas Gerais, by canine parasites in different developmental stages. Rev Inst Med Trop Sao Paulo 2013;55:229-31.

25. Adekeye TA, Thompson E, Awobode HO. Environmental contamination and public health risk of soil parasites in Ibadan South East Local Government Area, Nigeria. Zool Ecol 2016;26:150-7.

26. Momeni T, Mahami-Oskouei M, Fallah E, Safaiyan A, Mahami-Oskouei L. Latent and Asymptomatic Toxocara Infection among Young Population in Northwest Iran: The Necessity of Informing People as a Potential Health Risk. Scientifica 2016;2016:3562056. 